\title{
Integration of Photovoltaics into Gaza Strip Residential Buildings: A Comparison between Roof and Façade Installation
}

\author{
Omar S. Asfour \\ Department of Architectural Engineering, IUG \\ Gaza City, Palestinian Territories
}

\begin{abstract}
Several concerns face the world nowadays in the field of energy. Gaza Strip, the Palestinian Territories, shares a great deal of these concerns considering its limited resources. One main problem in this regard is the intermittent fuel supply. This has significantly affected electricity supply and, subsequently, economical growth and people's health and safety. This paper tackles this problem form a different point of view. It considers the current interruption of electrical power as an opportunity that could be invested to encourage people to use renewable energy sources. A simple photovoltaic $(P V)$ system has been suggested as a first step in this regard. The system is a standalone $P V$ system that could be simply installed in residential buildings. $P V$ panels can be installed directly on the roof or used as shading devices on the facades. The latter option has an additional environmental advantage, and makes PV panels visible, which is supposed to encourage their use in the society. It has been found that a PV area of $5 \mathrm{~m}^{2}$ can meet the basic needs of the Palestinian family. This area captures more solar radiation when installed on the roof in a $30^{\circ}$ tilt angle. PV inclined installation on southern façade reduces $P V$ exposure to solar radiation by about $15 \%$ due to the resulting shading effect.
\end{abstract}

Keywords: solar energy; sustainability; insolation; photovoltaic; shading device; Gaza

\section{Introduction}

As defined by the World Commission on Environment and Development, sustainable development is "development that meets the needs of the present without compromising the ability of future generation to meet their own needs" [1]. This definition has been followed by several ones that focus on specific fields of development, including architecture and urban planning. For example, the Building Services Research and Information Association (BSRIA) defined sustainable development as "the creation and management of healthy buildings based upon resource efficient and ecological principles" [2]. Energy here is clearly one of those resources that should be used efficiently and effectively.

During the last decades, the global concern over the use of fossil and nuclear fuels has increased due to their adverse effects on the environment. In addition, dependence on the conventional energy resources is no longer enough considering the rapid world population increase. It is estimated that global energy use will increase from $13.5 \mathrm{TW}$ in 1990 to $20.3 \mathrm{TW}$ in 2025 [3]. Thus, looking for alternative energy resources is essential for all aspects of our life. This includes the field of construction, where a great deal of energy is consumed in erecting and operating buildings. Buildings should be designed to maximize the use of free energies, and to reduce the consumption of energy at the construction, use, and disposal stages.

This is true in the case of Gaza Strip. Gaza Strip is a narrow strip located at the southern part of the Palestinian Territories. It has limited natural resources compared to the rapidly increasing population. This population increased from 1.02 to 1.42 million in the period spanning between 1997 and 2007. Assuming a stable growth rate following 2007 , Gaza Strip population will multiply in 21 years [4]. This increasing population lives in a congested built environment, where residential buildings form more than $75 \%$ of buildings [5]. In addition to this great challenge, Gaza Strip faces a persistent electricity crisis since 2007.

Reasons of this crisis are interrelated, and include political and economical factors. However, the remaining fact is that Gaza Strip faces a great shortage of electrical supply, which recently reached $52 \%$ [6]. This is mainly attributed to the shortage of fuel supplies used to operate the Gaza Power Plant. As a result of this shortage, the majority of Gaza population has been experiencing power cuts of 12 hours per day, which disrupts all aspects of their daily life. To deal with this situation, people use gasoline generators at their homes and work places to generate electricity. This is hazardous to both health and environment, and caused several household accidents and deaths. 
In front of this situation, a possible alternative is to encourage people to use renewable energy resources. This includes solar energy, which is abundantly available in the hot climate of Gaza Strip. Encouraging people to use solar energy to generate electricity is practical since they already use solar thermal energy for domestic water heating. Electricity can be generated from solar energy using photovoltaics (PVs).

\section{PV Use in Buildings}

PVs are devices, which directly convert the solar energy into electricity. A PV cell consists of a junction between two thin layers of dissimilar semi conducting materials. When the cell is exposed to the sun, the incident energy of light creates mobile charged particles in the semiconductor, which produce electrical current. PV cells are usually assembled into modules, which makes it easy to integrate them into buildings as several connected models called arrays. The produced electrical energy could be used for the private and public purposes. Private or domestic use includes electricity supply for lighting and operating small load applications, while public use includes electricity supply for street lighting and public services.

PV technologies vary and include several types. These types can be either amorphous or crystalline cells. Amorphous (thin film) cells are characterised by flexibility which makes them practical in cases such as curved roofs. However, their efficiency is the lowest. Crystalline cells can either be Monocrystalline or Polycrystalline cells. The first one is the most efficient and common in the market, while the latter one is less efficient but cheaper.

PVs can be independently installed on buildings using steel frames. However, using Building integrated Photovoltaics (BIPV) has additional advantages. Making PVs a constituent part of the building envelop offers improved aesthetics, reduces installation cost, and increases the area available for PV installation. In this regard, PVs can be:

- Integrated into building roof as skylights or cladding elements.

- Integrated into building façade as curtain walls or cladding elements.

- Used as horizontal or vertical shading devices.

In the latter option, PVs can be called 'solar shading devices' as they are used to prevent the building from overheating and provide clean electricity at the same time. In this case, PVs are incorporated into glass louvers and then used as fixed or movable opaque shading devices. They can be designed as usual shading devices in terms of geometrical characteristics considering sun angles and shading requirements.

To guard PV efficiency in this case, it is essential to keep it exposed to natural light as much as possible. This means that shading should be avoided. Shading can exist as a result of insufficient spacing of PV modules, dirt and dust, adjacent building components or vegetation, etc. Thus, place of installation should be selected carefully considering site conditions and building configuration, where even small obstacles shouldn't be neglected. In this regard, simulation programs are commonly used to carry out shading analysis, which simulates the annual sun movement and the resulting shading.

In addition, special attention has to be paid to the resulting heating of PVs. This is because increasing the operating temperature of the PV module can cause some damage to the system and undesired heat gains to the building. In the optimum case, there should be a balance between heat produced by the PV module and heat loss to the ambient environment. Natural ventilation is a common solution by raising PV modules off the roof and leaving a small gap between solar shading device and the wall.

Considering Gaza climatic and economic conditions, several studies have been carried out to examine the use of PVs. Muhaisen [7] discussed the persistent energy crises in Gaza Strip. He clarified its reasons and negative effects on the daily life and economy. The potential of using solar energy as a clean alternative was examined. The study found that plenty availability of solar radiation in Palestine makes the use of PV systems of great potential, especially in residential buildings which consumes most of electricity supplied to Gaza. However, the high cost of these systems form a main obstacle that need to be overcome.

Hussein, M., Albaraqouni [8] carried out an empirical study on PV use in Gaza Strip. The study firstly modelled the global solar radiation and evaluated several estimation methods in comparison to the observed meteorological data. The estimated values of these models where in a good agreement. Abu-Jasser [9] focused on the domestic application of PV systems. The study proposed a stand-alone photovoltaic system based on the Watt-Hour demand. System components have been sized including PV panels, batteries, and inverter. This has been done with reference to Gaza climate. It has been found that a PV area of about $11.5 \mathrm{~m}^{2}$ is required to meet a typical estimated daily load of $4.5 \mathrm{kWh}$.

Despite these efforts, the use of Building Integrated Photovoltaics (BIPV) considering the climate of Gaza requires further investigation. As discussed above, the use of PVs as shading devices is an attractive option in this regard due to its advantages. This is examined in the following modelling study. However, the proposed PV system has to be sized and configured firstly, which is detailed in the following section. 


\section{The Proposed PV System}

As discussed in the introduction, Palestinian electricity consumption is rapidly increasing due to the increasing rate of development and population growth. Solar energy represents a practical alternative considering the sunny and hot climatic conditions of the Palestinian Territories. Gaza has a Mediterranean climate with a relatively hot summer and mild winter. High levels of solar radiation are available in Gaza Strip throughout the year, as annual sunshine hours are about 3000 . The monthly average incident solar radiation (insolation) on horizontal surfaces ranges from $2.63 \mathrm{kWh} / \mathrm{m}^{2}$.day in December to $8.5 \mathrm{kWh} / \mathrm{m}^{2}$.day in June. The daily average of solar radiation intensity on horizontal surface is $5.46 \mathrm{kWh} / \mathrm{m}^{2}$.day [10]. Thus, it is possible to effectively use PV systems in different building types including residential ones.

\subsection{Description of the System}

As discussed in the introduction, continuous availability of grid electricity is not guaranteed in Gaza. Moreover, PV systems may be expensive for most Palestinian households. Thus, the proposed system is assumed off-grid with minimum requirements (Fig. 1). This stand-alone PV system consists of a PV array supplying a DC load. The use of an inverter, a device for converting direct to alternating current, makes it suitable for AC loads. A storage battery is usually used to supply electricity during the night. A charge regulator is used to block reverse current and prevent battery from getting overcharged or discharged.

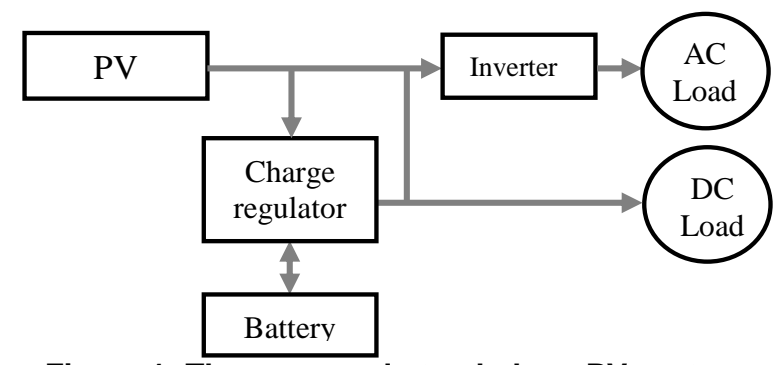

Figure 1: The proposed stand-alone PV system

\subsection{PV Sizing}

In order to estimate the required size of PV panels, it is essential firstly to estimate the expected load. The proposed system is intended for emergency cases and is expected to cover a minimum defined load. Table 1 shows an assumption in this regard, considering electricity supply for lighting and other small appliances.

Table 1: Estimated PV load

\begin{tabular}{|l|l|l|l|l|} 
Load & No. & Total & Daily & Load \\
\hline
\end{tabular}

\begin{tabular}{|l|l|l|l|l|l|}
\hline & $(\mathbf{W})$ & $\begin{array}{l}\text { of } \\
\text { units }\end{array}$ & $\begin{array}{l}\text { load } \\
(\mathbf{W})\end{array}$ & $\begin{array}{l}\text { operation } \\
\text { hours }\end{array}$ & $(\mathbf{k W h})$ \\
\hline Lighting & 30 & 6 & 180 & 8 & 1.44 \\
\hline TV & 100 & 1 & 100 & 4 & 0.4 \\
\hline Receiver & 20 & 1 & 20 & 4 & 0.08 \\
\hline Fan & 40 & 1 & 40 & 4 & 0.16 \\
\hline Total & & 2.08 \\
\hline Others (25\% of total) \\
Total $(\mathbf{k W h}$ /day)
\end{tabular}

PV required area can be estimated using two scenarios:

A. Scenario 1: This scenario assumes that the entire load can be met by PV. This means that: Total daily load $=$ PV output

Or,

$$
\text { Load }=S * A * \eta
$$

Where: $\mathrm{S}$ is solar energy, $\mathrm{A}$ is area of the array, $\eta$ is conversion efficiency of the PV array. The annual average solar radiation in the Palestinian territories is $5.46 \mathrm{kwh} / \mathrm{m}^{2}$.day on horizontal surface. PV efficiency is assumed 10\%. Considering this, Equation 2 can be rewritten as follows to estimate PV area:

$$
\begin{aligned}
A & =\operatorname{Load} /(S * \eta) \\
& =2.6 /(5.46 * 0.10)=4.8 \mathrm{~m}^{2}
\end{aligned}
$$

B. Scenario 2: This scenario assumes that the peak load can be met by PV. To find out this load, it is essential to consider the operational period for every appliance. Based on Table 1, Fig. 2 shows the distribution of the normal use of the different assumed appliances throughout the day.

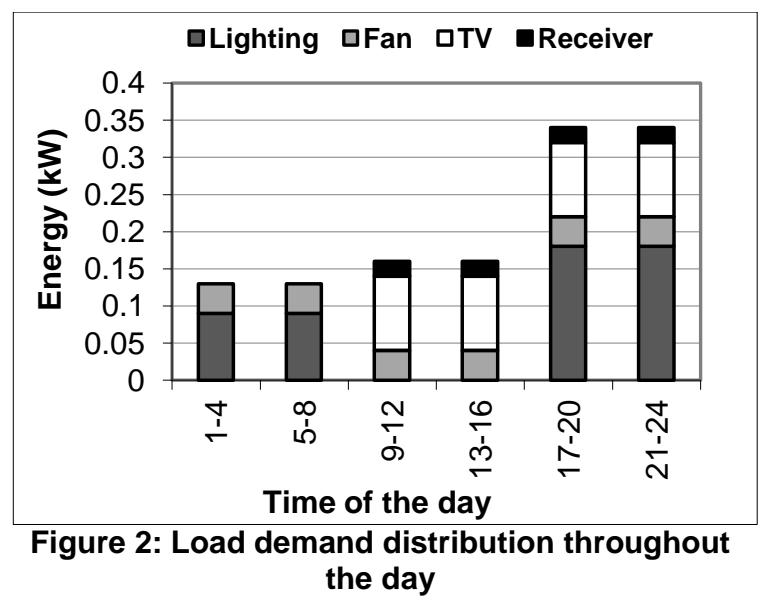

Hours have been divided into intervals, where every two ones cover the usual daily electrical power interruption in Gaza city (eight hours). Since a PV area of $4.8 \mathrm{~m}^{2}$ is assumed above, PV output based on equation 2 is:

$4.8 \mathrm{~m}^{2} * 5.45 \mathrm{kWh} / \mathrm{m}^{2}$.day $* 0.10=2.62 \mathrm{kWh} /$ day

The generation takes place during the day hours, which are assumed eight hours. So:

$\mathrm{PV}$ output rate $=2.62 \mathrm{kWh} / 8 \mathrm{~h}=0.327 \mathrm{~kW}$ 
Comparing this value to Fig. 2 shows that during electricity generation time, there is a surplus of the PV production compared to load demand $(0.327$ compared to $0.16 \mathrm{~kW}$, respectively). If electrical power interruption occurs during the daytime, the surplus amount can be used to charge the battery to be used during night. If electrical power interruption occurs during the night time, then the entire generated power can be used to charge the battery.

This rough estimation is based on some assumptions including PV output rate. To get more accurate estimation, it is more useful to rely on the real PV output rather than the rate. This needs detailed data about the monthly or even the hourly insolation (Fig. 3). This gives more accuracy, especially in battery sizing to secure electricity storage for the worst days, usually during winter, when it is dark and cloudy. In addition, despite that connections are not assumed complicated; there will be some losses due to electricity transmission.

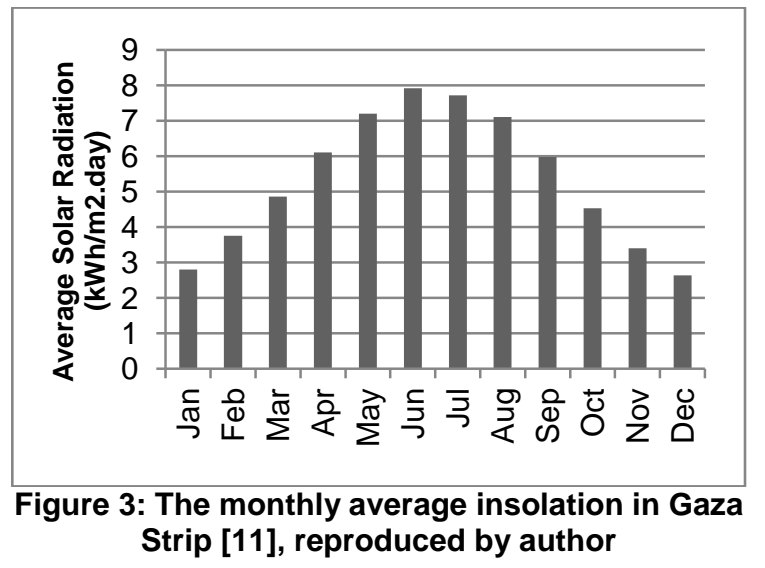

\section{PV Installation Modelling}

PV mounting should expose the array to the maximum possible solar radiation. Several factors are essential here such as shading effect and PV tilt angle. As for the first factor, PV panels should be located carefully to avoid self-shading and shadows from adjacent buildings or vegetation. As for the second one, sun angle varies between summer and winter. This means that each season has its own optimum tilt angle. This requires using either adjustable PV arrays or use fixed ones at a 'compromise angle' that considers both seasons. The latter option is more practical, especially in places where solar radiation is abundantly available. Tilt angle in this case is usually considered equal to the latitude ( $31^{\circ}$ in the case of Gaza Strip). Thus, PV tilt angle is assumed $30^{\circ}$ in this study.

To examine installation of the proposed PV system, a hypothetical case representing a $14 * 14 \mathrm{~m}$ residential block has been assumed. The block accommodates eight flats stacked in four floors, where each flat has a window area of $5 \mathrm{~m}^{2}$. The case has been modelled using Ecotect 5.5 software. Ecotect is a user-friendly conceptual thermal modelling tool with a three-dimensional interface to help modelling the examined building or group of buildings. In addition to the calculations of thermal comfort and heating and cooling loads; Ecotect can be used to quantify several variables including insolation.

This can be done using 'Solar Access Analysis' tool, where it is possible to display the distribution and availability of solar radiation over an entire building or group of buildings for a specific time, period, or for the whole year as an average. This is useful to study shading effect and demonstrate the best place for PV installation. The use of 'Solar Access Analysis' tool requires several inputs.

Firstly, the required quantitative variable has to be specified. A range of variables is available here such as sky factor and shading or sunlight hours. The desired option here is insolation, which calculates the amount of global, direct and diffuse solar radiation falling on selected objects (PV panels in this study). The following step is specification of calculation period. This option offers a list that determines the period over which the insolation value is averaged. This can be a single day or hour, a selected period of the year, or the entire year. This considers the current model latitude specified by the user.

After that, a selection of the required value has to be made. Estimation of insolation can be performed as a cumulative value for the specified period, as a daily/hourly average, or to find out the peak value. The daily average option has been used in this study. Finally, object overshadowing calculation technique has to be specified. In order to estimate insolation, ECOTECT needs to generate a shading mask for each object in the building. This aims to specify which part of the sky is visible and what percentage of the object is in shade. There is a range of accuracy levels for this process. The 'high' option has been selected in this study to get a detailed shading calculations.

To carry out the modelling process, it is essential to specify the city in which the building is located. This is done by specifying a climatic data file of the targeted city from the Ecotect program directory. As there is no such a file for Gaza city, the study relied on Al-Arish climatic data file due to the similarity between these two cities. Al-Arish is a coastal city in Egypt that is close to Gaza city. Both cities are located on latitude $31 \mathrm{~N}$. Average monthly temperature ranges from $13^{\circ} \mathrm{C}$ in Jan. to $26^{\circ} \mathrm{C}$ in Aug. in both cities [12].

PV installation has been examined in four cases, as follows:

- Case 1: PV roof installation.

- Case 2: PV southern façade installation.

- Case 3: PV eastern façade installation.

- Case 4: PV western façade installation. 
In each case, PV inclined and non-inclined (horizontal or vertical) installation have been examined and compared. Insolation values have been calculated as daily averages for the $1^{\text {st }}$ of June to represent summer time, and for the $1^{\text {st }}$ of December to represent winter time.

\subsection{Case 1: PV roof installation}

In this case, PV arrays are installed on the roof. A PV array is assumed for each flat in the block. This results in eight arrays, as shown in Fig. 4. Area of the array is assumed to match the calculated one in PV sizing, discussed in section 3.2 , i.e. $4.8 \mathrm{~m}^{2}$. This is assumed $5 \mathrm{~m}^{2}$ to facilitate the modelling process. Results were as follows:

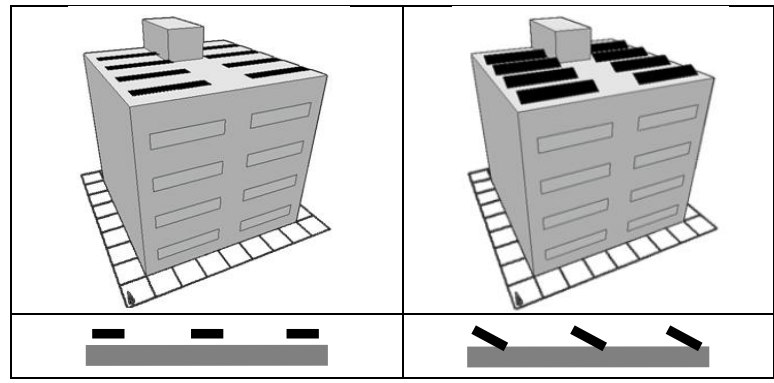

Figure 4: Case 1 showing PV arrays installed horizontally on the roof (left), and with a $30^{\circ}$ tilt angle (right)

A. PV horizontal installation: the estimated average daily insolation on horizontal surfaces is 6.5 $\mathrm{kWh} / \mathrm{m}^{2}$ in the $1^{\text {st }}$ of June, and $2.2 \mathrm{kWh} / \mathrm{m}^{2}$ in the $1^{\text {st }}$ of December. These values are promising for PV installation on the roof. However, they can be improved further by considering a tilt angle equivalent to Gaza latitude $\left(30^{\circ}\right)$.

B. PV inclined installation: PV arrays have been inclined at $30^{\circ}$ tilt angle towards the south. Spacing between arrays has been uniformly distributed, where shadow effect is avoided. The recorded average daily insolation is $5.9 \mathrm{kWh} / \mathrm{m}^{2}$ in the $1^{\text {st }}$ of June, and $3.5 \mathrm{kWh} / \mathrm{m}^{2}$ in the $1^{\text {st }}$ of December. This shows a reduction of $9 \%$ in summer insolation, and a significant increase of $60 \%$ in winter insolation. This makes the inclined installation more favorable, especially in winter when the sun is in low altitude.

\subsection{Case 2: PV southern façade installation}

To encourage the use of PV systems in Gaza, they can be integrated into building facades, which makes PV panels more exposed. As shown in Fig. 5, PV panels in this case can function as shading devices, which also gives the building an aesthetic appearance. This is usually optimum in the case of southern facades, where PVs are installed horizontally and spaced properly to avoid the resulting shading effect. Modelling results were as follows:

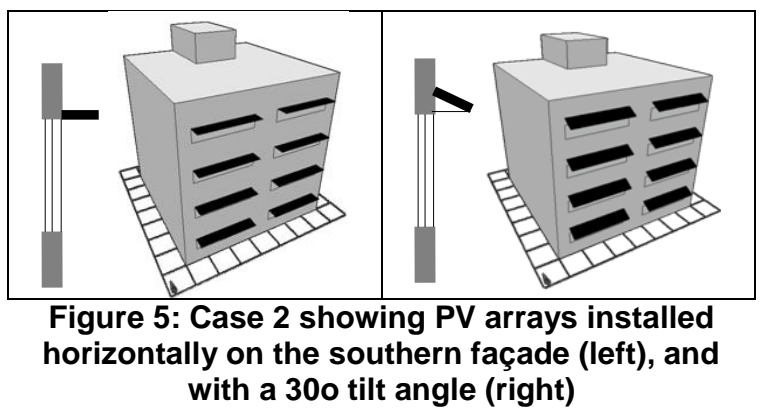

A. PV horizontal installation: Table (2) shows results obtained in this case. Due to the assumed building symmetry, the daily average insolation level on the proposed PV panels is presented as an average for each floor. It can be noticed that all measured values in summer are less than the ones observed in the case of PV roof installation $\left(6.5 \mathrm{kWh} / \mathrm{m}^{2}\right)$. Also, all measured values are almost the same, with the exception of the top floor in summer season, which recorded the highest insolation level $\left(5.4 \mathrm{kWh} / \mathrm{m}^{2}\right)$. This can be explained by the resulting shading on building façade in summer and the low sun altitude in winter (see Fig. 6).

Table 2: Estimated daily average insolation level on PV in summer and winter using horizontal and inclined PV installation on the southern façade

\begin{tabular}{|l|l|l|l|l|}
\hline \multirow{2}{*}{} & \multicolumn{3}{|c|}{$\begin{array}{c}\text { Daily average insolation level on PV } \\
\left(\mathbf{k W h} / \mathbf{m}^{\mathbf{2}}\right)\end{array}$} \\
\cline { 2 - 5 } & \multicolumn{3}{|c|}{$\begin{array}{c}\text { Horizontal } \\
\text { Installation }\end{array}$} & \multicolumn{2}{c|}{$\begin{array}{c}\text { Inclined } \\
\text { Installation }\end{array}$} \\
\hline $\begin{array}{c}\text { Period } \\
\text { Floor }\end{array}$ & Summer & Winter & Summer & Winter \\
\hline Ground & 3 & 2.1 & 3.4 & 3.6 \\
\hline $1^{\text {st }}$ & 3 & 2.1 & 3.4 & 3.6 \\
\hline $2^{\text {nd }}$ & 3.25 & 2.1 & 3.6 & 3.6 \\
\hline $3^{\text {rd }}$ & 5.4 & 2.2 & 5.4 & 3.6 \\
\hline Average & $\mathbf{3 . 7}$ & $\mathbf{2 . 1}$ & $\mathbf{4}$ & $\mathbf{3 . 6}$ \\
\hline
\end{tabular}

B. PV inclined installation: the model has been reexamined considering a PV tilt angle of $30^{\circ}$. Table 2 shows results obtained in this case. Compared to PV horizontal installation on the southern facade, it can be noticed that an improvement is observed mainly in winter, where insolation increased by $70 \%$ (from about 2.1 to $3.6 \mathrm{kWh} / \mathrm{m}^{2}$.day). This is not the case in summer where a slight improvement is only observed. This again is attributed to the effect of shadows since the top floor records the highest insolation value (see Fig. 6).

The resulting PV shading observed on building façade cannot be avoided here by increasing PV spacing, as it is restricted by floor height. Instead, PV depth have been reduced from $1 \mathrm{~m}$, as examined above, to $0.7 \mathrm{~m}$. Reducing $\mathrm{PV}$ depth has been 
compensated by increasing its length to ensure the same PV area provision.

Results showed that this measure has no significant impact, as the effect of shading is still persistent. Average insolation value received by each flat is $3.8 \mathrm{kWh} / \mathrm{m}^{2}$ in summer, and $3.5 \mathrm{kWh} / \mathrm{m}^{2}$ in winter. This is almost similar to the insolation value recorded in Case 2 before adjusting $\mathrm{PV}$ dimensions $\left(4 \mathrm{kWh} / \mathrm{m}^{2}\right.$ in summer, and $3.6 \mathrm{kWh} / \mathrm{m}^{2}$ in winter).

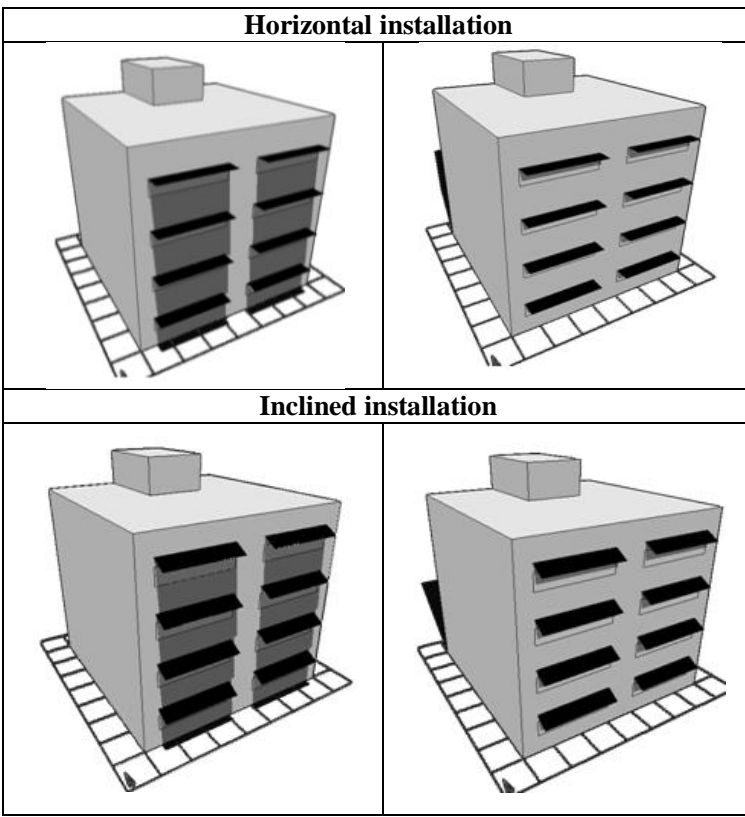

Figure 6: The resulting PV shadows over building southern façade at noon time in the $1^{\text {st }}$ of June (left) and the $1^{\text {st }}$ of December (right)

\subsection{Case 3: PV eastern façade installation}

If the building has no exposed southern façade, then PVs can be installed on the eastern or western façade. However, they have to be installed vertically to ensure better performance as shading devices. Also, they can be inclined towards the north to ensure better shading. Both options have been examined in this case and the following one (Fig. 7). Building geometrical parameters are assumed similar to the previous cases but in different orientations. Similar PV area has been provided, where four vertical PV panels with a total area of $40 \mathrm{~m}^{2}$ are assumed on the façade. This means that each flat of the eight flats will have a PV area of $5 \mathrm{~m}^{2}$. Modelling results were as follows:

Eastern façade

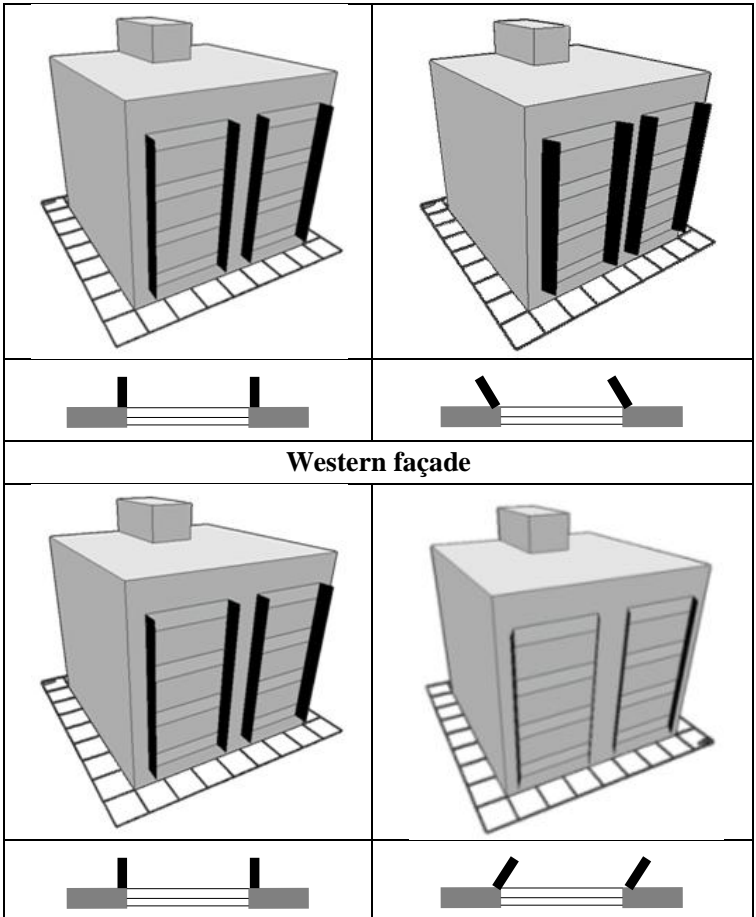

Figure 7: Case 3 (top) and 4 (bottom) showing PV arrays installed vertically on the façade (left), and with a $30^{\circ}$ tilt angle towards the north (right)

A. PV vertical installation: Results show different values of insolation received by each PV panel. These values vary between 1 and $1.5 \mathrm{kWh} / \mathrm{m}^{2}$ in summer, and 1.6 and $2.4 \mathrm{kWh} / \mathrm{m}^{2}$ in winter. In general, the external panel receives the highest value, while the internal ones receive less insolation as a result of PV shading. Taking the average of the four panels means that insolation value received by each flat is $1.2 \mathrm{kWh} / \mathrm{m}^{2}$ in summer, and $1.9 \mathrm{kWh} / \mathrm{m}^{2}$ in winter.

B. PV inclined installation: As mentioned above, this option is believed to provide better shading of the opening, and, in turn, better solar exposure of the shading device. Thus, the same shading devices are re-examined here considering a PV tilt angle of $30^{\circ}$. This angle is similar to the one used in Cases 1 and 2.

Results show different values of insolation received by each PV panel. These values vary between 2.2 and $2.5 \mathrm{kWh} / \mathrm{m}^{2}$ in summer, and 1.9 and $2.5 \mathrm{kWh} / \mathrm{m}^{2}$ in winter. Taking the average of the four panels means that insolation value received by each flat is $2.4 \mathrm{kWh} / \mathrm{m}^{2}$ in summer, and $2.2 \mathrm{kWh} / \mathrm{m}^{2}$ in winter. Thus, the inclined installation advantage appears mainly in summer, where insolation value is doubled (2.4 compared to $\left.1.2 \mathrm{kWh} / \mathrm{m}^{2}\right)$.

\subsection{Case 4: PV western façade installation}

This case is similar to the previous one. PVs are installaed vertically on the western façade and then 
inclined by $30^{\circ}$ towards the north. Modelling results were as follows:

A. PV vertical installation: Results show different values of insolation received by each PV panel. Taking the average of the four panels means that insolation value received by each flat is $1.3 \mathrm{kWh} / \mathrm{m}^{2}$ in summer, and $1.6 \mathrm{kWh} / \mathrm{m}^{2}$ in winter.

B. PV inclined installation: Results show similar behaviour of the one observed in the eastern facade. However, insolation increase is less significant. The average insolation value received by each flat is 1.7 $\mathrm{kWh} / \mathrm{m}^{2}$ in summer, and $1.8 \mathrm{kWh} / \mathrm{m}^{2}$ in winter. Thus, the inclined installation caused an increase of 30 and $12 \%$ in summer and winter, respectively.

Table 3 summarises the results obtained in the modelling study. It shows the average daily insolation values obtained in summer and in winter. It is clear that the best performance in summer is observed in Case 1, where PVs are installed horizontally on the roof. However, the best performance in winter is observed in Case 2, where $\mathrm{PV}$ s are inclined on the southern facade.

Table (3): Estimated daily average insolation level on PV in summer and winter for the different modeling cases

\begin{tabular}{|l|l|c|c|}
\hline \multicolumn{2}{|c|}{ Insolation } & \multicolumn{2}{|c|}{$\begin{array}{c}\text { Average insolation level on } \\
\text { PV }\left(\mathbf{k W h} / \mathbf{m}^{\mathbf{2}}\right)\end{array}$} \\
\cline { 3 - 4 } Case & $\begin{array}{c}\text { Summer } \\
\left(1^{\text {st }} \text { of Jun. }\right)\end{array}$ & $\begin{array}{c}\text { Winter } \\
\left(1^{\text {st }} \text { of Dec. }\right)\end{array}$ \\
\hline \multirow{2}{*}{ Case 1 } & Horizontal & $\mathbf{6 . 5}$ & 2.2 \\
\cline { 2 - 4 } & Inclined & 5.9 & 3.5 \\
\hline \multirow{2}{*}{ Case 2 } & Horizontal & 3.7 & 2.1 \\
\cline { 2 - 4 } & Inclined & 4.0 & $\mathbf{3 . 6}$ \\
\hline \multirow{2}{*}{ Case 3 } & Vertical & 1.2 & 1.9 \\
\cline { 2 - 4 } & Inclined & 2.4 & 2.2 \\
\hline \multirow{2}{*}{ Case 4 } & Vertical & 1.3 & 1.6 \\
\cline { 2 - 4 } & Inclined & 1.7 & 1.8 \\
\hline
\end{tabular}

Fig. 8 summarises the results obtained in the modelling study as annual average. It can be noticed that the best performance in general is observed in the case of PV inclined installation on the roof. This case recorded an average annual insolation of 4.6 $\mathrm{kWh} / \mathrm{m}^{2}$. The lowest insolation level is observed in the case of vertical PV installation on both eastern and western façade. The highest inolation level received by PVs installed on building facades is observed in the case of inclined installation on the southern façade $\left(3.9 \mathrm{kWh} / \mathrm{m}^{2}\right)$. This is lower than the best case mentioned above by $15 \%$. However, this difference can be compromised considering the benefit of installing PVs as shading devices, and the benefit of exposing PV systems to people, which is hoped to encourage their use in the society.

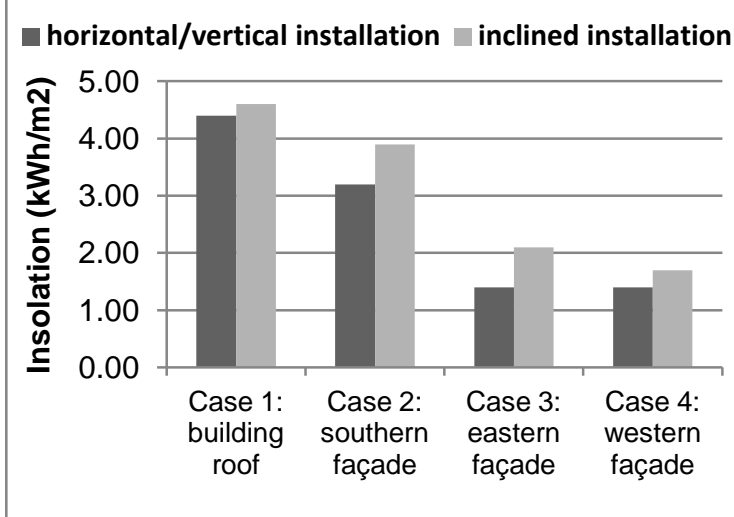

Figure 8: A comparison between the average annual insolation received by PVs in the different modeling cases

\section{Conclusion}

The global concern about the adverse effects of conventional energy sources depletion is increasing. Several alternatives have been introduced and developed over the past decades, including integration of renewable energy systems into buildings. As part of these efforts, this paper discussed the electricity crises in Gaza Strip and the potential use of PV systems as part of the solution. PVs could be simply installed and used in residential buildings to partially substitute the daily electrical power interruption considering the abundant availability of solar radiation in Gaza Strip. Encouraging people to use this type of renewable energy is practical since they already use solar thermal energy for domestic water heating. In addition, PV use can be encouraged using some governmental incentives, such as tax exemption and direct funding.

In this regard, a simple stand-alone PV system with a PV area of $5 \mathrm{~m}^{2}$ can meet the basic needs of the Palestinian family. This system can be installed onto building facades as shading devices, which gives additional advantage of the system. Also, this integration method makes PV panels visible, which is supposed to encourage their use in the society. This is more effective in the case of PV inclined installation on southern façade by $30^{\circ}$. However, the disadvantage of this installation is that it reduces amount of captured solar radiation by about $15 \%$, when compared to the inclined installation on the roof. This reduction occurs mainly in summer due to the resulting PV shading effect. However, southern façade performance may be improved by limiting the effect of PV shading. In this regard several options can be examined such as replacing PV panels by PV blinds, and increasing PV area using PV as cladding element.

The work presented in this study may be advanced to examine other variables such as other integration options of PVs into buildings. This 
includes the use of PV skylights and curtain walls considering Gaza climatic conditions. In addition, PV spacing may be optimized to maximize PV performance while reducing or eliminating selfshading effect. The use of movable PV shading devices and grid-connected systems may be examined to maximize electricity generation as well.

Finally, in addition to the use of PV systems, additional efforts are required to support sustainability principles in the Palestinian built environment. This includes, but not limited to, the use of water and energy-efficient systems, green building materials, and eco- friendly waste management.

\section{References}

[1] WCED (1987), Our Common Future, Oxford University Press, Oxford.

[2] Edwards, B. and Hyett, P. (2001) Rough Guide to Sustainability, RIBA publications, London.

[3] Boyle G. (1996) Renewable Energy: Power for a Sustainable Future, Oxford University Press, Oxford.

[4] PCBS (2007) 'Census 2007' PCBS website; http://www.pcbs.gov.ps/pcbs_2012/Publications.aspx (13 April 2012).

[5] PCBS (2009) 'Percentage Distribution of Completed Buildings in the Palestinian Territory by Utilization of Building and Region, 2007' PCBS website; http://www.pcbs.gov.ps/Portals/_PCBS/Downloads/book1 624/book1624_0501.pdf (5 November 2012).

[6] GEDCO (no date) 'Statistics and Reports: Technical Statistics' GEDCO website: http://www.gedco.ps/reports.php (8 November 2013).

[7] Muhaisen, A. (2007) 'The Energy Problem in Gaza Strip and its Potential Solution' In proceedings of ICEEP 2007, Palestine Polytechnic University, Hebron, Plaestine. [8] Hussein, M., Albaraqouni, S. (2011) 'Re-Evaluation and Re-Design Stand-Alone PV Solar Lighting Projects in Gaza Strip, Palestine', The Islamic University Journal (Series of Natural Studies and Engineering) 19 (1), pp. 323 $-337$.

[9] Abu-Jasser, A. (2010) 'A Stand-Alone Photovoltaic System, Case Study: A Residence in Gaza' Journal of Applied Sciences in Environmental Sanitation 5 (1), pp. 81-91.

[10] Mahmoud M., and Ibrik I. (2006) 'Techno-economic feasibility of energy supply of remote villages in Palestine by PV-systems, diesel generators and electric grid' Renewable and Sustainable Energy Reviews 10, pp. 128138.

[11] PEA, Renewable Energy Department (no date) 'Climate Data' PEA website; http://peapal.tripod.com/renewable_energy_department.htm (13 April 2013).

[12] Weatherbase.com (2013) 'Records and Averages for Middle East' Weatherbase website; www.weatherbase.com (15 October 2012). 